\title{
Urinary 1-aminopyrene level in Koreans as a biomarker for the amount of exposure to atmospheric 1-nitropyrene
}

\author{
Bolormaa Ochirpurev $^{1} \cdot$ Sang-Yong Eom ${ }^{1,2} \cdot$ Akira Toriba $^{3} \cdot$ Yong-Dae Kim $^{1,2} \cdot$ Heon Kim $^{1,2}(\mathbb{D}$
}

Received: 30 December 2020 / Revised: 12 March 2021 / Accepted: 15 March 2021 / Published online: 3 April 2021

(c) The Author(s) 2021

\begin{abstract}
1-Nitropyrene (1-NP) is a major nitro-polycyclic aromatic hydrocarbon (nitro-PAH), and a common constituent in diesel exhaust particles (DEPs). Absorbed 1-nitropyrene is partly metabolized to 1-aminopyrene and excreted in urine. Recently, the number of diesel cars has been increasing, which could be a major cause of air pollution, resulting elevated levels of traffic-related DEPs around cities. The aim of this study was to investigate the usability of 1-aminopyrene (1-AP) as a biomarker for DEP exposure by examining the association between urinary 1-AP concentration and the amount of exposure to atmospheric 1-NP. The study subjects included 65 individuals who work on vehicular roads or bus terminals. Their $24 \mathrm{~h}$ urine samples were collected, and atmospheric air was sampled using a personal air sampler for $24 \mathrm{~h}$. Urinary 1-AP and atmospheric nitro-PAH levels were measured using a high-pressure liquid chromatography-fluorescence detector (HPLCFD). The average urine 1-AP concentration was $0.334 \mathrm{pg} / \mathrm{g}$ creatinine. Urinary 1-AP levels were significantly correlated with 1-NP level exposure $(\mathrm{r}=0.385, p=0.002)$ but not with the other nitro-PAHs. When the subjects were classified into high-and low-exposure groups, a significant association was only found in the high exposure group $(\mathrm{r}=0.357, p=0.045)$. In conclusion, there was a significant correlation between 1-NP exposure and urinary 1-AP concentration; therefore, urinary 1-AP level could be used as an exposure biomarker for DEP.
\end{abstract}

Keywords 1-Nitropyrene $\cdot$ Urinary 1 -aminopyrene $\cdot$ Diesel exhaust particle $\cdot$ Nitro-PAH

\section{Introduction}

1-Nitropyrene (1-NP), an important nitro-polycyclic aromatic hydrocarbon (nitro-PAH) and a major constituent in diesel exhaust particles (DEPs), is mutagenic and carcinogenic to humans and has been classified into group 2A by the International Agency for Research on Cancer [1-4]. Absorbed 1-nitropyrene is partly metabolized to 1-aminopyrene and excreted in urine. Recently, the number of diesel cars has been increasing, which could be a major cause

Heon Kim

kimheon@cbu.ac.kr

1 Department of Preventive Medicine, College of Medicine, Chungbuk National University, 1 Chungdae-ro, Seowon-gu, Cheongju 28644, Republic of Korea

2 Chungbuk National University Hospital, 776, 1Sunhwan-ro, Seowon-gu, Cheongju, Republic of Korea

3 Department of Hygienic Chemistry, Graduate School of Biomedical Science, Nagasaki University, Nagasaki 852-8521, Japan of traffic-related DEP air pollution around cities. Inhaled 1-NP is metabolized by nitro-reduction and P450-mediated ring oxidation and excreted through urine in the form of glucuronide and sulfate. Nine metabolites of 1-NP were detected in in vivo studies: hydroxy-1-nitropyrenes (3-, 6-, and 8-OHNP), hydroxyl- $N$-acetyl-1-aminopyrenes (3-, 6-, and 8-OHNAAP), $N$-acetyl-1-aminopyrene (NAAP), 1 -aminopyrene (1-AP), and trans-4,5-dihydro-4,5-dihydroxy1-nitropyrene) [5-7].

Urinary concentrations of these metabolites can be used to assess exposure to DEP. However, whether the urinary concentrations of these substances are statistically related to DEP exposure levels has not been adequately verified. Although a significant association between urinary 1-AP level and elemental carbon exposure has been reported [8-13], no study has studied the relationship between 1-NP exposure and 1-AP excretion.

The main goal of this study was to investigate the possibility of using 1-AP as a biomarker for DEP exposure by examining the association between 1-AP concentration in urine and the 1-NP exposure level. 


\section{Materials and methods}

\section{Study subjects}

This study was conducted after review and approval by the Chungbuk National University Bioethics Committee (IRB). The study subjects were 65 Cheongju residents who were recruited from a group expected to be occupationally exposed to DEP. Among them, 16 were Yakurt delivery and sales females, 8 were bus terminal workers, 37 were street sweepers, and 4 were office workers. They signed the consent form after being informed of the study in detail and provided blood and $24 \mathrm{~h}$ urine samples.

A direct interview was conducted using a questionnaire that included questions on demographic characteristics, working environments, dietary patterns, and diesel car use.

The subjects were divided into two groups. Those with 1-NP exposure above average were classified into the high exposure group, and those with below average exposure were classified into the low exposure group.

\section{Measurement of nitro-PAH concentrations in the atmosphere}

Air was sampled at a flow rate of $3 \mathrm{~L} / \mathrm{min}$ for $24 \mathrm{~h}$ with a personal air sampler (Apex standard, SN0376420 Casella CEL, Bedford, England) with a filter holder attached to the collars of the subjects. PTFE filters with a pore size of $2 \mu \mathrm{m}$ were used. The filters were placed in a flask and mixed with dichloromethane $(2 \mathrm{~mL})$. The flask was shaken and treated with ultrasonic waves to extract PAHs and nitro-PAHs. The extracts were evaporated to dryness and the residue was redissolved in acetonitrile. Aliquots of the solution were then injected into a two-dimensional high-performance liquid chromatography (HPLC) system with a fluorescence detector (FD) for the quantification of PAHs and nitro-PAHs [14]. The injected sample was eluted through a clean-up column (Cosmosil, 5NPE, $150 \times 4.6 \mathrm{~mm}$ i.d., $5 \mu \mathrm{m}$, Nacalai Tesque, Kyoto, Japan) with guard column $1(10 \times 4.6 \mathrm{~mm}$ i.d. $)$, and nitro-PAHs were reduced to their amino-derivatives using a reduction column (NPpak-RS, $10 \times 4.6 \mathrm{~mm}$ i.d., JASCO, Tokyo, Japan) at $80{ }^{\circ} \mathrm{C}$. The mobile phase for the clean-up and reduction columns was an ethanol/acetate buffer ( $\mathrm{pH} 5.5)$ $(95 / 5, \mathrm{v} / \mathrm{v})$ at a flow rate of $0.2 \mathrm{~mL} / \mathrm{min}$. A fraction of the amino derivatives and unchanged PAHs eluted from the reduction column with the mobile phase were mixed with $30 \mathrm{mM}$ ascorbic acid at a flow rate of $1.6 \mathrm{~mL} / \mathrm{min}$ and then trapped on the concentration column (Spheri-5 RP-18, $30 \times 4.6 \mathrm{~mm}$ i.d. $5 \mu \mathrm{m}$, Perkin Elmer, MA, USA). The concentrated fraction was passed through two separation columns (Inertsil ODS-P, $250 \times 4.6 \mathrm{~mm}$ i.d., $5 \mu \mathrm{m}$, GL Sciences, Tokyo, Japan) with a guard column $(10 \times 4.6 \mathrm{~mm}$ i.d.) in tandem. All columns, except the reduction column, were maintained at $20^{\circ} \mathrm{C}$. A programmed gradient elution of the separation columns was performed using $10 \mathrm{mM}$ imidazole buffer ( $\mathrm{pH}$ 7.6) as eluent A and acetonitrile as eluent B. Finally, the separated analytes were detected with their optimum excitation and emission wavelengths by the dual-channel FD. Eighteen nitro-PAHs, including 1,3-, 1,6-, and 1,8-dinitropyrene (1,3-, 1,6- and 1,8-DNP), 2-nitrofluorene (2-NF), 9-nitrophenathrene (9-NPh), 2and 9-nitroanthracene (2- and 9-NA), 1-, 2-, and 3-nitrofluoranthrene (1-, 2- and 3-NFR), 1-, 2-, and 4-nitropyrene (1-, 2-, and 4-NP), 7-nitrobenz[a]anthracene (7-NBaA), 6-nitrochrysene (6-NC), 6-nitrobenz[a]pyrene (6-NBaP), 1-nitroperylene (1-NPer), and 3-nitroperylene (3-NPer), were measured as analytes (Fig. S1).

\section{Measurement of urinary 1-aminopyrene}

Urinary 1-AP levels were measured from $2 \mathrm{~h}$ urine samples. One milliliter of $10 \mathrm{M}$ hydrochloric acid was added to each $10 \mathrm{~mL}$ urine sample, and the urine was stirred in a $90-{ }^{\circ} \mathrm{C}$ water bath for $2 \mathrm{~h}$. After adjusting the $\mathrm{pH}$ to $7.0-8.0$, the supernatant was extracted with Sep-Pak cartridge (C18, $3 \mathrm{~mL}, 200 \mathrm{mg}$, Waters, Milford, UK). Before extraction, it was pre-conditioned with $5 \mathrm{~mL}$ of methanol and $5 \mathrm{~mL}$ of water. After loading the sample, it was washed with $5 \mathrm{~mL}$ of $20 \%$ methanol in water and then extracted with $4 \mathrm{~mL}$ of $100 \%$ methanol. The extract was dried with $\mathrm{N}_{2}$ gas and dissolved in $200 \mu \mathrm{L}$ of methanol. The extract was analyzed by injecting $20 \mu \mathrm{L}$ into the HPLC system equipped with a fluorescence detector (Shimadzu, RF-20A, Kyoto, Japan). A reverse phase-amide column (Ascentis RP-Amide, $25 \mathrm{~cm} \times 4.6 \mathrm{~mm}, 5 \mu \mathrm{m}$, SUPELCO, Bellefonte, PA, USA) was used. The mobile phase was composed of methanol and $50 \mathrm{mM}$ sodium acetate buffer $\mathrm{pH} 7.2(80: 20, \mathrm{v} / \mathrm{v})$ at a flow rate of $1.0 \mathrm{~mL} / \mathrm{min}$, and the excitation and emission wavelengths were $254 \mathrm{~nm}$ and $425 \mathrm{~nm}$, respectively (Fig. 1). Urinary 1-AP concentration was corrected using the urinary creatinine level.

\section{Statistical analysis}

Statistical analysis was performed using IBM SPSS Statistics 24.0 (IBM Corp., Armonk, NY, USA). The concentrations of nitro-PAH in the air and 1-AP in urine were analyzed for outliers by plotting a scatterplot. To prevent statistical significance distortion by extreme values, the confirmed outliers were replaced with mean $+2 \times$ standard deviation values. The difference between the two groups in the concentration of nitro-PAH in air and the concentration of nitroPAH metabolites in urine was compared using the Student's 
Fig. 1 Chromatograms for 1-aminopyrene (a 1-aminopyrene standard $10 \mathrm{ng} / \mathrm{ml}$, b urine sample)
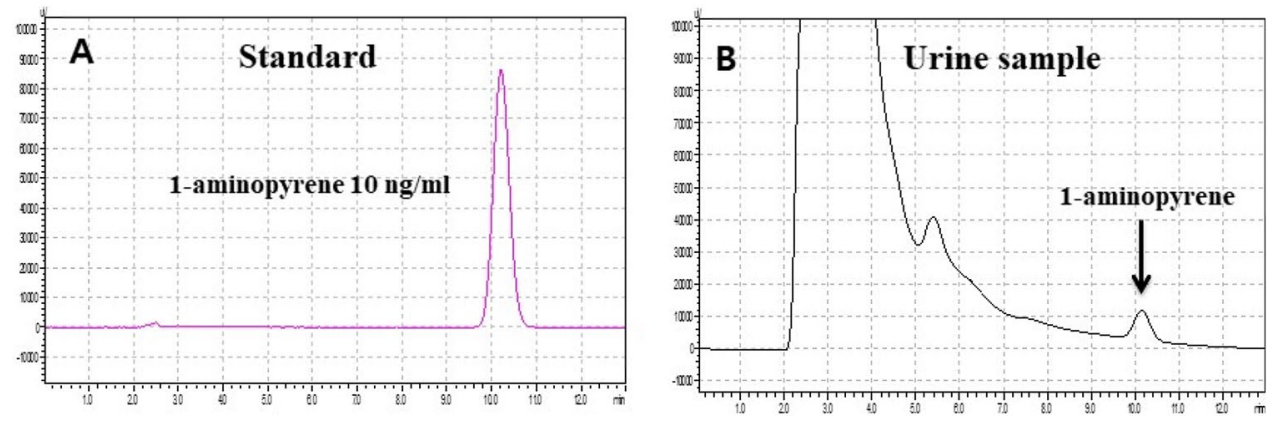

$t$ test or Mann-Whitney test, and the comparison between the three groups was analyzed using one-way ANOVA or the Kruskal-Wallis test. The relationship between urinary 1-AP concentration and the exposure levels of nitro-PAHs, including 1-NP, was statistically tested using Pearson's correlation analysis and a general linear model. All statistical analyses were determined to be statistically significant at a significance level of $<0.05$.

\section{Results}

Figure 2 shows the distribution of urinary 1-AP and seven atmospheric nitro-PAHs.

The urinary concentration of 1-AP and levels of exposure to 1-NP and total nitro-PAHs according to the demographic characteristics of the study subjects are presented
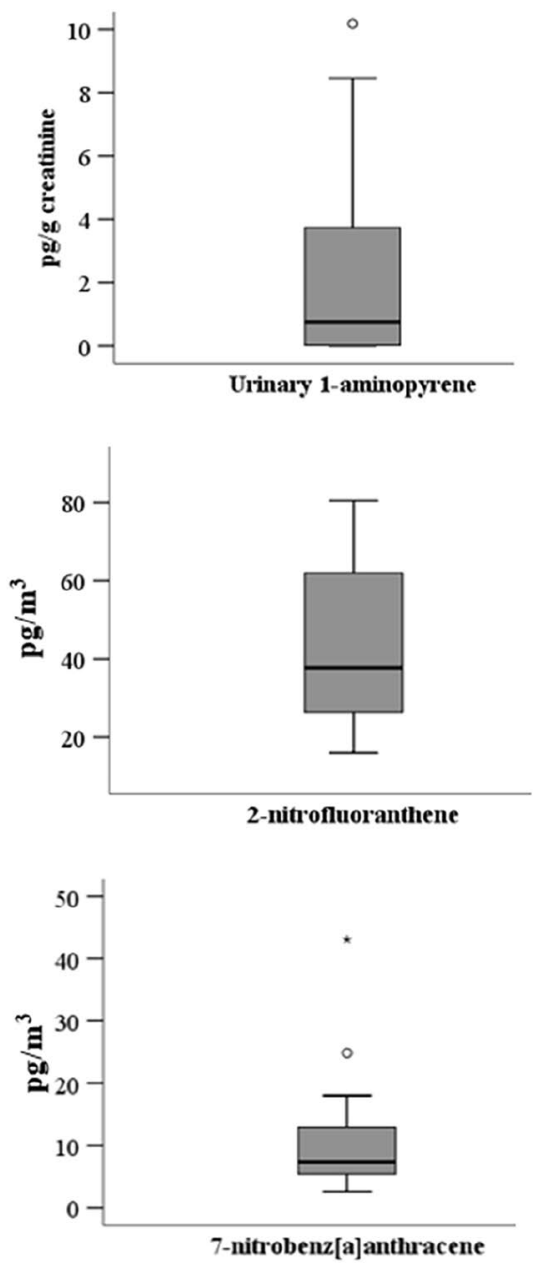
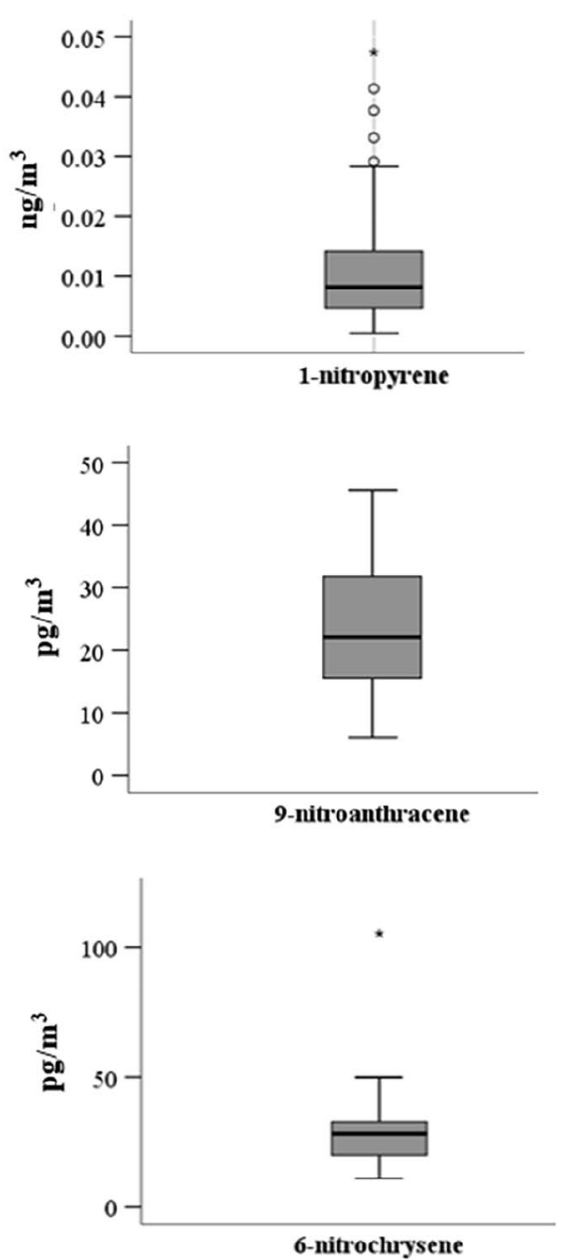
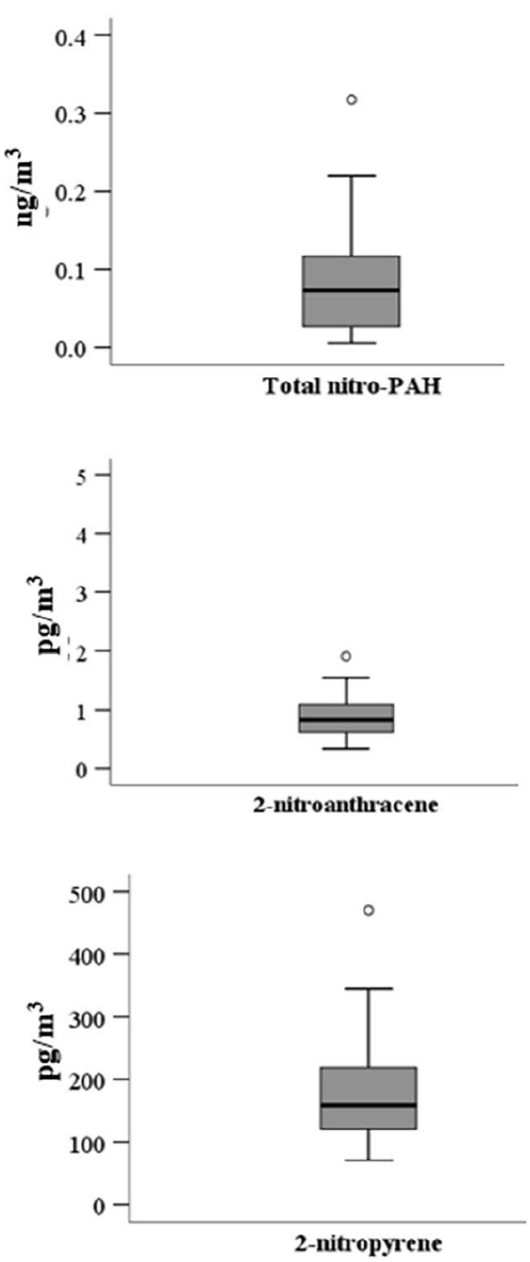

Fig. 2 Distribution of urinary 1-aminopyrene and atmospheric nitro-PAH concentrations 
Table 1 Atmospheric nitro-PAH and urinary 1-AP levels according to general characteristics

\begin{tabular}{|c|c|c|c|c|c|c|c|}
\hline \multirow[t]{2}{*}{ Characteristics } & \multirow[t]{2}{*}{ No $(\%)$} & \multicolumn{6}{|c|}{ Geometric mean (95\% Confidence interval) } \\
\hline & & 1-AP (pg/g creatinine) & $p$ & 1-Nitropyrene $\left(\mathrm{ng} / \mathrm{m}^{3}\right)$ & $p$ & Total nitro-PAHs $\left(\mathrm{ng} / \mathrm{m}^{3}\right)$ & $p$ \\
\hline All subject & $65(100)$ & $0.334(0.161,0.691)$ & & $0.009(0.006,0.011)$ & & $0.053(0.040,0.069)$ & \\
\hline Occupation & & & $0.232^{\mathrm{a}}$ & & $0.174^{\mathrm{a}}$ & & $0.060^{\mathrm{a}}$ \\
\hline Bus terminal worker & $8(12)$ & $0.413(0.063,2.726)$ & & $0.005(0.004,0.008)$ & & $0.108(0.074,0.159)$ & \\
\hline Street cleaner & $37(57)$ & $0.289(0.002,50.717)$ & & $0.010(0.007,0.014)$ & & $0.053(0.038,0.073)$ & \\
\hline Yakurt delivery ladies & $16(25)$ & $0.425(0.149,1.214)$ & & $0.006(0.003,0.012)$ & & $0.036(0.017,0.074)$ & \\
\hline Office workers & $4(6)$ & $0.179(0.040,0.794)$ & & $0.018(0.001,0.227)$ & & $0.059(0.015,0.233)$ & \\
\hline Sex & & & $0.121^{\mathrm{b}}$ & & $0.968^{\mathrm{b}}$ & & $0.282^{\mathrm{b}}$ \\
\hline Males & $47(72)$ & $0.410(0.170,0.992)$ & & $0.009(0.007,0.013)$ & & $0.061(0.046,0.080)$ & \\
\hline Females & $18(28)$ & $0.195(0.050,0.762)$ & & $0.007(0.004,0.012)$ & & $0.036(0.019,0.069)$ & \\
\hline Smoking status & & & $0.188^{\mathrm{b}}$ & & $0.595^{\mathrm{b}}$ & & $0.102^{\mathrm{b}}$ \\
\hline Non-smokers & $34(52)$ & $0.289(0.110,0.757)$ & & $0.008(0.006,0.011)$ & & $0.044(0.030,0.065)$ & \\
\hline Current or ex-smokers & $31(48)$ & $0.392(0.123,1.244)$ & & $0.009(0.006,0.014)$ & & $0.064(0.044,0.093)$ & \\
\hline Current smoking & & & $0.133^{\mathrm{b}}$ & & $0.092^{\mathrm{b}}$ & & $0.797^{\mathrm{b}}$ \\
\hline No & $14(22)$ & $0.816(0.107,6.192)$ & & $0.015(0.007,0.032)$ & & $0.059(0.031,0.113)$ & \\
\hline Yes & $17(26)$ & $0.214(0.051,0.895)$ & & $0.006(0.004,0.01)$ & & $0.069(0.042,0.112)$ & \\
\hline Road adjacency & & & $0.520^{\mathrm{b}}$ & & $0.564^{\mathrm{b}}$ & & $0.798^{\mathrm{b}}$ \\
\hline$<50 \mathrm{~m}$ & $39(60)$ & $0.215(0.079,0.582)$ & & $0.008(0.006,0.011)$ & & $0.055(0.039,0.077)$ & \\
\hline$\geq 50 \mathrm{~m}$ & $26(40)$ & $0.647(0.224,1.870)$ & & $0.009(0.006,0.015)$ & & $0.050(0.032,0.078)$ & \\
\hline Diesel car ownness & & & $0.127^{\mathrm{b}}$ & & $0.464^{\mathrm{b}}$ & & $0.830^{\mathrm{b}}$ \\
\hline Yes & $28(43)$ & $0.405(0.119,1.382)$ & & $0.010(0.006,0.016)$ & & $0.054(0.036,0.081)$ & \\
\hline No & $37(57)$ & $0.288(0.114,0.730)$ & & $0.008(0.005,0.011)$ & & $0.052(0.036,0.075)$ & \\
\hline Outdoor activity & & & $0.126^{\mathrm{b}}$ & & $0.827^{\mathrm{b}}$ & & $0.876^{\mathrm{b}}$ \\
\hline$\leq 8 \mathrm{~h}$ & $20(31)$ & $0.306(0.085,1.106)$ & & $0.007(0.004,0.012)$ & & $0.053(0.031,0.090)$ & \\
\hline$>8 \mathrm{~h}$ & $45(69)$ & $0.347(0.139,0.866)$ & & $0.009(0.007,0.013)$ & & $0.053(0.038,0.072)$ & \\
\hline Roasted meat consumption & & & $0.140^{\mathrm{b}}$ & & $0.372^{\mathrm{b}}$ & & $0.834^{\mathrm{b}}$ \\
\hline$\leq 3$ day & $37(57)$ & $0.364(0.139,0.952)$ & & $0.010(0.007,0.014)$ & & $0.056(0.041,0.078)$ & \\
\hline$>3$ day & $28(43)$ & $0.297(0.091,0.972)$ & & $0.007(0.005,0.011)$ & & $0.048(0.030,0.076)$ & \\
\hline Season & & & $0.080^{\mathrm{b}}$ & & $0.652^{\mathrm{b}}$ & & $0.256^{\mathrm{b}}$ \\
\hline High & $37(57)$ & $0.186(0.077,0.448)$ & & $0.008(0.006,0.012)$ & & $0.060(0.042,0.086)$ & \\
\hline Low & $28(43)$ & $0.725(0.213,2.471)$ & & $0.009(0.006,0.014)$ & & $0.044(0.030,0.066)$ & \\
\hline
\end{tabular}

ANOVA (a) and $t$ test (b) were used for the statistical analysis

in Table 1. The average 1-AP concentration was $0.334 \mathrm{pg} / \mathrm{g}$ creatinine (men: $0.41 \mathrm{pg} / \mathrm{g}$ creatinine; women: $0.195 \mathrm{pg} / \mathrm{g}$ creatinine). The 1-AP and 1-NP levels did not significantly differ according to gender, smoking habit, occupation, location of residence, driving of diesel cars, participation in outdoor activities, or consumption grilled meat.

The geometric mean of 1-NP and total nitro-PAH exposure levels were $0.009 \mathrm{ng} / \mathrm{m}^{3}$ and $0.053 \mathrm{ng} / \mathrm{m}^{3}$, respectively. The mean values for males were slightly higher than those for females, but there was no significant difference in the other variables.

The association between quantified nitro-PAHs (9-NA, 2-NA, 2-NFR, 1-NP, 7-NBaA, 6-NC, 2-NP, and total NP) and urinary 1-AP was analyzed using Pearson's correlation analysis (Table 2). These nitro-PAHs were quantified for all samples, but the others were not detected or were under quantification limits. For all subjects, the correlation coefficients between 1-NP exposure and urinary 1-AP excretion in $2 \mathrm{~h}$ urine samples were significant $(\mathrm{r}=0.385$, $p=0.002$ ), especially in the high exposure group. However, 1-AP excretion in the $2 \mathrm{~h}$ urine samples did not show a significant correlation with the other nitro-PAHs (Table 2).

A positive association was observed between creatinineadjusted 1-AP levels and 1-NP exposure levels, in a multivariate analysis that controlled for age, sex, smoking status, roasted meat consumption, occupation, outdoor activity, season, road adjacency, and diesel car ownership (Table 3). As the 1-NP concentration increased by $1 \mathrm{pg} / \mathrm{m}^{3}$, the $1-\mathrm{AP}$ concentration increased by $0.262 \mathrm{pg} / \mathrm{g}$ creatinine. All other covariates were not significantly correlated with the creatinine-adjusted 1-AP levels (Table 3). 
Table 2 Pearson correlation coefficients between urinary excretion of 1-AP and environmental exposure to nitro-PAHs

\begin{tabular}{|c|c|c|c|c|c|c|c|c|c|}
\hline \multirow[t]{2}{*}{ Nitro-PAHs } & \multicolumn{3}{|c|}{ Total } & \multicolumn{3}{|c|}{ 1-NP low exposure } & \multicolumn{3}{|c|}{ 1-NP high exposure } \\
\hline & $\mathrm{n}$ & $\mathrm{r}$ & $\mathrm{p}$ & $\mathrm{n}$ & $\mathrm{r}$ & $\mathrm{p}$ & $\mathrm{n}$ & $\mathrm{r}$ & $\mathrm{p}$ \\
\hline 9-NA & 33 & -0.179 & 0.320 & 15 & -0.041 & 0.885 & 18 & -0.277 & 0.267 \\
\hline 2-NA & 26 & -0.138 & 0.503 & 9 & 0.007 & 0.986 & 17 & -0.173 & 0.506 \\
\hline 2-NFR & 65 & -0.093 & 0.461 & 33 & -0.313 & 0.076 & 32 & -0.153 & 0.403 \\
\hline $1-\mathrm{NP}$ & 65 & 0.385 & 0.002 & 33 & -0.176 & 0.328 & 32 & 0.357 & 0.045 \\
\hline 7-NBaA & 39 & -0.218 & 0.183 & 17 & -0.412 & 0.100 & 22 & -0.137 & 0.545 \\
\hline $6-\mathrm{NC}$ & 40 & -0.184 & 0.256 & 19 & -0.509 & 0.026 & 21 & -0.138 & 0.552 \\
\hline 2-NP & 52 & -0.239 & 0.088 & 25 & -0.506 & 0.010 & 27 & -0.310 & 0.116 \\
\hline Total NP & 65 & 0.050 & 0.690 & 33 & -0.390 & 0.025 & 32 & 0.009 & 0.961 \\
\hline
\end{tabular}

Table 3 Parameter estimates for a general linear model for 1-AP (pg/g creatinine)

\begin{tabular}{lrl}
\hline & \multicolumn{1}{l}{ beta } & $\mathrm{p}$ \\
\hline Intercept & -0.010 & 0.785 \\
Age (year) & 0.000 & 0.198 \\
Sex & 0.021 & 0.070 \\
Smoking status (yes, no) & 0.010 & 0.172 \\
Roasted meat consumption $(>3$ day) & 0.007 & 0.216 \\
Occupation & -0.008 & 0.158 \\
Outdoor activity $(>8 \mathrm{~h})$ & 0.003 & 0.599 \\
Season (high) & -0.012 & 0.069 \\
Road adjacency (<50 m) & 0.005 & 0.354 \\
Diesel car owned (yes) & -0.005 & 0.364 \\
1-NP pg/m & \\
$\mathrm{R}^{2}$ & 0.262 & 0.001 \\
\hline
\end{tabular}

\section{Discussion}

This study is the first to simultaneously measure urinary 1-AP excretion and exposure to atmospheric nitro-PAHs in Korean residents. The average 1-NP level was $8.5 \mathrm{pg} /$ $\mathrm{m}^{3}$ for all participants in this study. Recently, Hayakawa et al. [15] reported the levels of atmospheric 1-NP and 6-NBaP in five cities, including Busan, South Korea. The median atmospheric 1-NP concentration ranged from 12 to $91 \mathrm{fmol} / \mathrm{m}^{3}$, which corresponded to $3.0-22.5 \mathrm{pg} / \mathrm{m}^{3}$, and the average 1-NP concentration in the present study was within this range. The median and interquartile range 1-NP levels of US-Mexico border commuters were 0.96 and $0.33-1.87 \mathrm{pg} / \mathrm{m}^{3}$, respectively, and those of non-border commuters were 0.15 and $0.05-0.30 \mathrm{pg} / \mathrm{m}^{3}$, respectively [16], which were much lower than the mean values of this present study. A 1994 study in Kanazawa (Japan) found that the level of atmospheric 1-NP was $32 \mathrm{pg} / \mathrm{m}^{3}$, substantially higher than that in this study, and decreased over time to below the Korean average [17]. However, 1-NP levels in cities in Peru and China were much higher than those in this study. The level of $1-\mathrm{NP}$ was $104 \pm 31 \mathrm{pg} / \mathrm{m}^{3}$ in Trujillo [12], and approximately $80 \mathrm{pg} / \mathrm{m}^{3}$ in Shenyang, China [18].

1-AP levels did not show any differences according to age, sex, smoking status, roasted meat consumption, occupation, outdoor activity, season, road adjacency, and diesel car ownership. Some previous studies have also reported that the level of 1-AP does not statistically differ with smoking status $[19,20]$.

Neophytou et al. [20] reported that median urinary 1-AP concentrations of 82 male U.S trucking industry workers was $28.7 \mathrm{pg} / \mathrm{mg}$ creatinine. The median time-weighted-average concentrations of urinary 1-AP was 138.7 and $21.7 \mathrm{ng} \mathrm{g}^{-1}$ creatinine for DEP-exposed subjects and clean air exposed controls [9]. These values were both significantly higher than the mean of the present study.

Assuming that the daily excretion of creatinine in urine is approximately $2 \mathrm{~g}$, the urinary excretion of 1-AP was 8.2 and $3.9 \mathrm{pg}$ in the male and female subjects of this study, respectively. Since the respiratory rate per minute is approximately $7 \mathrm{~L}$, the amount of 1-NP exposed is $90.7 \mathrm{pg}$ and $70.6 \mathrm{pg}$ in males and females, respectively. Therefore, $10.3 \%$ and $6.3 \%$ of 1-NP in males and females, respectively, was metabolized to 1-AP and excreted via urine. In contrast, the amount of urinary 1-AP excretion was greater than that of 1-NP exposure in most previous studies [9].

We observed a significant relationship between 1-NP exposure and urinary 1-AP excretion in $2 \mathrm{~h}$ urine samples. However, 1-AP excretion in the $2 \mathrm{~h}$ urine samples did not show a significant correlation with the other nitro-PAHs (9-NA, 2-NA, 2-NFR, 7-NBaA, 6-NC, 2-NP). Interestingly, 1-AP was associated with 1-NP in the high exposure group, but not in the low exposure group (Table 2). A similar significant relationship in a high DEP exposure group has also been reported in a previous study [9].

We observed a positive association between creatinineadjusted 1-AP and 1-NP exposure levels in a multivariate analysis controlling for age, sex, smoking status, road adjacency, season, and diesel car ownership. All other covariates were not significantly correlated with the creatinine-adjusted 
1-AP levels (Table 3). Studies on traffic workers $[8,10,16]$ have shown a positive correlation between 1-NP exposure levels and urinary concentrations of 1-NP metabolites (6-OHNP, 8-OHNP, and 8-OHNAAP); however, 1-AP was not measured in these studies.

The limitations of this study were that there was an insufficient number of subjects, and the distinction between the exposed and control groups was not clear.

This cross-sectional design was another limitation of this study. The peak urinary 1-AP excretion time could be longer than $24 \mathrm{~h}$ after exposure. To determine when the urinary excretion of 1-AP is highest after exposure to 1-NP, urinary 1-AP levels in serial urine samples should be measured. In this study, however, only urinary excretion of 1-AP between 22 and $24 \mathrm{~h}$ after exposure was measured. Furthermore, there could be individual differences in the metabolic rate of 1-NP; however, this polymorphism was not controlled for in our study.

Supplementary Information The online version contains supplementary material available at https://doi.org/10.1007/s43188-021-00096-z.

Funding This work was supported by the National Research Foundation of Korea (NRF) grant funded by the Korea government (MSIT) (No. 2017R1A2B4012066).

\section{Compliance with ethical standards}

Conflict of interest The authors have no conflict of interest to disclose.

Open Access This article is licensed under a Creative Commons Attribution 4.0 International License, which permits use, sharing, adaptation, distribution and reproduction in any medium or format, as long as you give appropriate credit to the original author(s) and the source, provide a link to the Creative Commons licence, and indicate if changes were made. The images or other third party material in this article are included in the article's Creative Commons licence, unless indicated otherwise in a credit line to the material. If material is not included in the article's Creative Commons licence and your intended use is not permitted by statutory regulation or exceeds the permitted use, you will need to obtain permission directly from the copyright holder. To view a copy of this licence, visit http://creativecommons.org/licenses/by/4.0/.

\section{References}

1. Ball LM, Rafter JJ, Gustafsson JA, Gustafsson BE, Kohan MJ, Lewtas J (1991) Formation of mutagenic urinary metabolites from 1-nitropyrene in germ-free and conventional rats: role of the gut flora. Carcinogenesis 12:1-5. https://doi.org/10.1093/carcin/ 12.1.1

2. Bamford HA, Bezabeh DZ, Schantz S, Wise SA, Baker JE (2003) Determination and comparison of nitrated-polycyclic aromatic hydrocarbons measured in air and diesel particulate reference materials. Chemosphere 50:575-587. https://doi.org/10.1016/ s0045-6535(02)00667-7

3. Benbrahim-Tallaa L, Baan RA, Grosse Y, Lauby-Secretan B, El Ghissassi F, Bouvard V, Guha N, Loomis D, Straif K, International Agency for Research on Cancer Monograph Working Group
(2012) Carcinogenicity of diesel-engine and gasoline-engine exhausts and some nitroarenes. Lancet. Oncol. 13:663-664. https://doi.org/10.1016/s1470-2045(12)70280-2

4. IARC Working Group on the evaluation of carcinogenic risks to humans (2014) Diesel and gasoline engine exhausts and some nitroarenes. IARC Monographs on the Evaluation of Carcinogenic Risks to Humans, No. 105. International Agency for Research on Cancer, Lyon (FR). https://www.ncbi.nlm.nih.gov/books/NBK29 4269/

5. Howard PC, Flammang TJ, Beland FA (1985) Comparison of the in vitro and in vivo hepatic metabolism of the carcinogen 1-nitropyrene. Carcinogenesis 6:243-249. https://doi.org/10.1093/carcin/ 6.2.243

6. Howard PC, Consolo MC, Dooley KL, Beland FA (1995) Metabolism of 1-nitropyrene in mice: transport across the placenta and mammary tissues. Chem Biol Interact 95:309-325. https://doi. org/10.1016/0009-2797(94)03574-r

7. van Bekkum YM, van den Broek PH, Scheepers PT, Bos RP (1998) Sensitive and selective detection of urinary 1-nitropyrene metabolites following administration of a single intragastric dose of diesel exhaust particles (SRM 2975) to rats. Chem Res Toxicol 11:1382-1390. https://doi.org/10.1021/tx980162x

8. Toriba A, Kitaoka H, Dills RL, Mizukami S, Tanabe K, Takeuchi N, Ueno M, Kameda T, Tang N, Hayakawa K, Simpson CD (2007) Identification and quantification of 1-nitropyrene metabolites in human urine as a proposed biomarker for exposure to diesel exhaust. Chem Res Toxicol 20:999-1007. https:// doi.org/10.1021/tx700015q

9. Laumbach R, Tong J, Zhang L, Ohman-Strickland P, Stern A, Fiedler N, Kipen H, Kelly-McNeil K, Lioy P, Zhang J (2009) Quantification of 1-aminopyrene in human urine after a controlled exposure to diesel exhaust. J Environ Monit JEM 11:153-159. https://doi.org/10.1039/b810039j

10. Miller-Schulze JP, Paulsen M, Kameda T, Toriba A, Tang N, Tamura K, Dong L, Zhang X, Hayakawa K, Yost MG, Simpson CD (2013) Evaluation of urinary metabolites of 1-nitropyrene as biomarkers for exposure to diesel exhaust in taxi drivers of Shenyang. China J Expo Sci Environ Epidemiol 23:170-175. https://doi.org/10.1038/jes.2012.40

11. Gong J, Zhu T, Kipen H, Rich DQ, Huang W, Lin WT, Hu M, Zhang JJ (2015) Urinary polycyclic aromatic hydrocarbon metabolites as biomarkers of exposure to traffic-emitted pollutants. Environ Int 85:104-110. https://doi.org/10.1016/j.envint. 2015.09.003

12. Miller-Schulze JP, Paulsen M, Kameda T, Toriba A, Hayakawa K, Cassidy B, Naeher L, Villalobos MA, Simpson CD (2016) Nitro-PAH exposures of occupationally-exposed traffic workers and associated urinary 1-nitropyrene metabolite concentrations. J Environ Sci (China) 49:213-221. https://doi.org/10.1016/j.jes. 2016.06.007

13. Du M, Mullins BJ, Franklin P, Musk AW, Elliot N, Sodhi-Berry N, Junaldi E, de Klerk N, Reid A (2019) Measurement of urinary 1-aminopyrene and 1-hydroxypyrene as biomarkers of exposure to diesel particulate matter in gold miners. Sci Total Environ 685:723-728. https://doi.org/10.1016/j.scitotenv.2019. 06.242

14. Boongla Y, Orakij W, Nagaoka Y, Tang N, Hayakawa K, Toriba A (2017) Simultaneous determination of polycyclic aromatic hydrocarbons and their nitro-derivatives in airborne particulates by using two-dimensional high-performance liquid chromatography with on-line reduction and fluorescence detection. Asian J Atmos Environ 11:283-299. https://doi.org/10.5572/ajae.2017. 11.4.283

15. Hayakawa K, Tang N, Nagato E, Toriba A, Lin JM, Zhao L, Zhou Z, Qing W, Yang X, Mishukov V, Neroda A, Chung HY (2020) Long-term trends in urban atmospheric polycyclic aromatic 
hydrocarbons and nitropolycyclic aromatic hydrocarbons: China, Russia, and Korea from 1999 to 2014. Int J Environ Res Public Health 17:431. https://doi.org/10.3390/ijerph17020431

16. Galaviz VE, Quintana PJ, Yost MG, Sheppard L, Paulsen MH, Camp JE, Simpson CD (2017) Urinary metabolites of 1-nitropyrene in US-Mexico border residents who frequently cross the San Ysidro Port of Entry. J Expo Sci Environ Epidemiol 27:84-89. https://doi.org/10.1038/jes.2015.78

17. Murahashi T, Hayakawa K (1997) A sensitive method for the determination of 6-nitrochrysene, 2-nitrofluoranthene and 1-, 2- and 4-nitropyrenes in airborne particulates using high-performance liquid chromatography with chemiluminescence detection. Anal Chim Acta 343:251-257. https://doi.org/10.1016/S00032670(96)00632-0
18. Miller-Schulze JP, Paulsen M, Toriba A, Tang N, Hayakawa K, Tamura K, Dong L, Zhang X, Simpson CD (2010) Exposures to particulate air pollution and nitro-polycyclic aromatic hydrocarbons among taxi drivers in Shenyang, China. Environ Sci Technol 44:216-221. https://doi.org/10.1021/es802392u

19. Seidel A, Dahmann D, Krekeler H, Jacob J (2002) Biomonitoring of polycyclic aromatic compounds in the urine of mining workers occupationally exposed to diesel exhaust. Int J Hyg Environ Health 204:333-338. https://doi.org/10.1078/1438-4639-00116

20. Neophytou AM, Hart JE, Chang Y, Zhang JJ, Smith TJ, Garshick E, Laden F (2014) Short-term traffic related exposures and biomarkers of nitro-PAH exposure and oxidative DNA damage. Toxics 2:377-390. https://doi.org/10.3390/toxics2030377 